\title{
KAJIAN NILAI BUDAYA \\ PADA ARSITEKTUR TRADISIONAL DI GIRI JAYA PADEPOKAN KABUPATEN SUKABUMI PROVINSI JAWA BARAT
}

\author{
Oleh Lina Herlinawati \\ Balai Pelestarian Sejarah dan Nilai Tradisional Bandung \\ Jln. Cinambo No. 136 Ujungberung Bandung \\ Email: lina.emul.000@yahoo.co.id
}

Naskah diterima: 25 juni 2010

Naskah disetujui: 6 September 2010

Abstrak

Giri Jaya Padepokan yang terletak di kaki Gunung Salak, tepatnya di Desa Giri Jaya, Kecamatan Cidahu, Kabupaten Sukabumi, memiliki bangunan-bangunan lama yang berarsitektur tradisional. Bangunan-bangunan tersebut perlu diperhatikan, dipelihara, dan dilestarikan keberadaannya. Pelestarian bangunan tersebut juga sekaligus melestarikan keterkaitan antara bangunan dan kehidupan komunitas manusianya, baik sehari-hari maupun ritual. Bagaimana konsep bangunan dalam struktur, fungsi, serta bentuk bangunan tidak banyak orang mengenalnya. Untuk itu, melalui penelitian yang bersifat deskripsi dengan pendekatan kualitatif dapatlah dipahami konsep-konsep tersebut. Dari hasil kajian tersebut, dapat dinyatakan bahwa bentuk-bentuk bangunan peninggalan leluhur Giri Jaya Padepokan itu selain memiliki bentuk bangunan berarsitektur tradisional Sunda, juga pada beberapa bagian bangunan ada pengaruh arsitektur Jawa dan Kolonial Belanda. Hal itu bisa terjadi karena leluhur Giri Jaya Padepokan sebagai pendiri bangunan tersebut memiliki pengalaman yang berkaitan dengan keberadaan Kolonial Belanda di Tatar Sunda serta pertemanannya dengan seseorang yang berasal dari "Mangku Negara" Surakarta.

Kata kunci: Giri Jaya Padepokan, arsitektur tradisional.

\begin{abstract}
The village of Giri Jaya Padepokan that lies on the foothill of Mount Salak has many buildings of traditional architecture. These buildings have to be preserved. To preserve those buildings means to preserve the relationship between the buildings themselves and the life of the community. There are very few people who have knowledge about the those traditiional buildings in term of structure and functions, as well as the shape. In understanding these concepts the author conducted a descriptive research method with qualitative approach. The author came into conclusion that despite of traditional Sundanese architecture, some of the buildings were influenced by both Javanese and Dutch colonial styles. The styles were adopted during their period of ruling Sundaland over centuries.
\end{abstract}

Keywords: Giri Jaya Padepokan, traditional architecture. 


\section{A. PENDAHULUAN}

Achmad Bagoes P.W. (1995), mengatakan bahwa dengan memperhatikan dan memelihara sebuah karya seni bangunan, tidak lebih dan tidak kurang dari penghargaan yang merujuk pada memayu ayuning bhuwana, menyempurnakan kehidupan jagat. Jadi, apa yang telah dibangun dan berdiri, bukan sekadar dilihat kepentingannya dengan kebutuhan teknis pragmatis masa kini, tetapi lebih dari itu, yakni memperluas dan mendalami pemahaman manusia akan karyanya sendiri. Karya seni bangunan dari mana pun dan oleh siapa pun sebaiknya dilihat sebagai bagian dari keberadaan total yang terbuka untuk dihargai. Penghargaan ini bukan semata-mata tindakan tujuan romantik, tetapi untuk membuka dan memperkaya sumber-sumber pembangunan peradaban masa kini dan mendatang.

Jawa Barat memiliki banyak bangunan lama - termasuk bangunan yang berarsitektur tradisional, yang perlu diperhatikan dan dipelihara keberadaannya. Pelestarian bangunanbangunan tersebut menuntut pemikiran kembalinya hakikat keberadaannya di tengah kehidupan komunitas sekarang. Dengan pemikiran kekinian, yang perlu dilestarikan bukan semata-mata bangunannya, tetapi keterkaitan antara bangunan dan kehidupan komunitas manusia, baik sehari-hari maupun ritual.

Bangunan-bangunan yang berarsitektur tradisional, yang ada di daerah-daerah di Jawa Barat, di antaranya melingkupi bangunanbangunan tempat tinggal, tempat pertemuan, dan tempat penyimpanan.
Penciptaan elemen-elemen, bentuk, dan struktur arsitektur bangunan tersebut disesuaikan dengan lingkungan alam geografis dimana bangunan tersebut didirikan. Selain itu tersedianya atau melimpahnya suatu bahan tertentu dari suatu tempat juga menentukan arsitektur bangunan yang dibuat.

Berdasarkan pengaruh bahan, bentuk-bentuk, dan konstruksi arsitektur-arsitektur daerah tersebut, hal itu mencerminkan ciri kreativitas kedaerahannya (local genius). Masingmasing telah menunjukkan adanya variasi yang kaya dengan nuansanuansa etnik dan sikap spiritual para penghuninya.

Sebagaimana diketahui,

Kampung Adat Giri Jaya - yang terletak di Desa Giri Jaya, Kecamatan Cidahu, Kabupaten Sukabumi, dimana penelitian ini diadakan, adalah merupakan salah satu daerah yang ada di wilayah Provinsi Jawa Barat, yang memiliki ciri kebudayaan tersendiri. Kebudayaan yang mereka miliki adalah warisan para leluhurnya, yang hingga kini masih mereka pelihara dengan baik. Termasuk dalam bidang arsitektur bangunan-bangunan yang ada di sana, seperti bangunan tempat tinggal, tempat pertemuan, tempat penyimpanan, dan sebagainya. Sesepuh adatnya sendiri menamakan Giri Jaya sebagai kampung adat atau lembur adat dengan nama Padepokan Giri Jaya atau terakhir berganti nama menjadi Giri Jaya Padepokan.

Pemukiman warga Giri Jaya Padepokan yang terletak di kaki Gunung Salak, yang jauh dari pemukiman masyarakat desa pada umumnya, tentunya banyak mempengaruhi keutuhan bentuk-bentuk 
bangunan yang ada di lingkungannya. Terlebih kedudukan adat dan kepercayaan warisan leluhur mereka begitu kuat dalam proses pembangunan dan pemeliharaan bangunan-bangunan tersebut, sehingga keaslian dan kekhasannya selalu terjaga dengan baik.

Bagaimana konsep warga Giri Jaya Padepokan dalam struktur, fungsi, serta bentuk bangunan tidak banyak orang mengenalnya. Oleh karena itu, penelitian tentang Kajian Nilai Budaya pada Arsitektur Tradisional di Giri Jaya Padepokan Kabupaten Sukabumi Provinsi Jawa Barat ini, merupakan kegiatan yang cukup penting dalam upaya mengangkat dan menggali potensi nilai luhur budaya warisan para pendahulu di negeri ini, khususnya di daerah Jawa Barat.

Tujuan dari penelitian ini adalah untuk menggali dan memahami peranan adat atau tradisi dalam kehidupan masyarakat Giri Jaya Padepokan yang berkaitan dengan arsitektur tradisional. Wilayah penelitian adalah di Kampung/Giri Jaya Padepokan, Desa Giri Jaya, Kecamatan Cidahu, Kabupaten Sukabumi, Provinsi Jawa Barat, dengan materi yang akan dikaji adalah berbagai hal yang berkaitan dengan struktur bangunan, fungsi bangunan, dan bentuk bangunan. Komponen-komponen tersebut menjadikan suatu bentuk bangunan sebagai tempat untuk melakukan aktivitas kehidupan sehari-hari. Hal lain yang berpengaruh terhadap eksistensi arsitektur di Giri Jaya Padepokan adalah potensi sosial budaya masyarakatnya.

Penelitian yang digunakan bersifat deskripsi dengan pendekatannya kualitatif. Data yang dikumpulkan adalah data primer dan sekunder. Data sekunder, penulis peroleh dari studi pustaka, dengan cara mempelajari arsip-arsip dan literatur yang menunjang pelaksanaan penelitian. Adapun data primer, penulis peroleh dengan cara pengamatan, wawancara, dan pemotretan.

Dalam mengkaji permasalahan pada penelitian ini, kiranya perlu terlebih dahulu dijelaskan beberapa konsep yang terdapat di dalamnya, guna menjadi acuan dan rumusan untuk kepentingan operasional. Konsepkonsep tersebut yaitu konsep kebudayaan dan arsitektur.

Kebudayaan dapat diartikan sebagai keseluruhan hasil dan proses dari budi daya dengan manusia yang bersumberkan pada cipta, rasa, dan karsa dalam menciptakan tata kehidupan yang bermakna, dinamik, dan berkesinambungan. Hasil dari proses budi daya manusia terwujud sebagai ilmu pengetahuan, teknologi, dan kesenian, yang kesemuanya dimaksudkan untuk meningkatkan kualitas kehidupan yang lebih bermakna (Setjoatmodjo, P., 1981/1982 : 81).

Syafwandi (1985 : 49) menyebutkan bahwa, arsitektur merupakan bagian sistem tata nilai suatu masyarakat. Ia adalah cerminan tata nilai tersebut, yang berwujud bangunan dan struktur-struktur yang ada. Arsitektur sebagai hasil karya manusia, dipengaruhi antara lain oleh keadaan geografis, geologis, dan iklim. Ketiga hal ini membantu secara fisik penjelmaan bentuk arsitektur. Adapun keadaan keagamaan dan kemasyarakatan, turut serta menentukan taraf peradaban.

Dikatakan pula, bahwa dalam menilai dan mengerti suatu gaya atau 
bentuk arsitektur dari zaman lampau sama halnya seperti menilai dan mengerti peninggalan-peninggalan benda-benda kesenian lainnya dengan masalah-masalahnya. Kadangkala memang jelas karena petunjukpetunjuk yang ditinggalkan cukup banyak. Baik secara langsung yang terdapat pada bangunan itu sendiri, maupun secara tak langsung, dengan melalui penelaahan terhadap bidang arkeologi, sastra, bahkan antropologi, dan lain-lain. Tetapi sering pula ada peninggalan-peninggalan yang lepas dari konteks, sehingga sukar sekali untuk menangkap maksud dan tujuan, serta untuk mengetahui kapan dan siapa pendiri suatu bangunan. Tentu saja hal ini disebabkan petunjuk-petunjuk yang diperlukan tidak lengkap atau musnah dimakan waktu, ataupun memang tak pernah ada.

Arsitektur tradisional adalah suatu unsur kebudayaan yang tumbuh dan berkembang bersamaan dengan pertumbuhan dan perkembangan suatu suku bangsa atau etnik yang bersangkutan. Dalam arsitektur tradisional terkandung secara terpadu wujudwujud ideal, sosial, dan material suatu kebudayaan.

Dalam pembabakan sejarah arsitektur Indonesia, yang dikemukakan Djauhari Sumintardja dalam Syafwandi (1985), disebutkan ada lima babak, yaitu Rumah Tradisional, Arsitektur Hindu, Arsitektur Masa Kebudayaan Islam, Arsitektur Masa Penjajahan Barat, dan Perkembangan Arsitektur di Masa Empat Windu Merdeka. Istilah rumah tradisional dapat diartikan sebuah rumah yang dibangun dan digunakan dengan cara yang sama sejak beberapa generasi, dengan ciri penyangga lantai, segi konstruksi yang dibangun dengan kolong atau tiang yang tinggi, sehingga kolong rumah dapat dimanfaatkan sebagai tempat menyimpan barang misalnya. Arsitektur masa kebudayaan Hindu adalah sejumlah arsitektur dari jaman dan tempat dari suatu lingkungan masyarakat Hindu, dengan ciri terpentingnya adalah dalil-dalilnya tersusun dalam kitab keagamaan silpa sastra. Arsitektur masa kebudayaan Islam adalah sejumlah arsitektur dari jaman dan tempat dari suatu lingkungan masyarakat Islam. Kekayaan arsitektur kebudayaan Islam di Indonesia meliputi bangunan masjid, istana, menara, dan makam-makam. Ciri khasnya, khususnya di Jawa adalah bangunannya mengandung unsur-unsur Hindu. Arsitektur masa penjajahan Barat adalah arsitektur yang direncanakan dengan ide Barat. Di Indonesia, ciri Barat mulai tampak ketika Portugis datang (abad XVI) untuk berdagang rempah-rempah, kemudian dekade berikutnya Belanda datang. Selanjutnya perkembangan arsitektur di masa empat windu merdeka, yang dimulai tahun 1948 (Syafwandi, $1985: 51$ ).

\section{B. HASIL DAN BAHASAN}

Secara administratif Kampung Adat/Giri Jaya Padepokan termasuk dalam wilayah Desa Giri Jaya, Kecamatan Cidahu, Kabupaten Sukabumi. Letaknya kurang lebih 12 $\mathrm{km}$ dari Cicurug arah barat daya dan berada di kaki Gunung Salak (1.211 m) dan mempunyai ketinggian $800 \mathrm{~m} \mathrm{dpl}$. Wilayah tersebut berbatasan dengan daerah lain di sekelilingnya, yang meliputi : di sebelah timur berbatasan 
dengan Desa Cisaat Kecamatan Cicurug, di sebelah utara dengan kehutanan, di sebelah barat dengan Desa Cidahu Kecamatan Cidahu, dan di sebelah selatan dengan Desa Tangkil Kecamatan Cidahu. Letak Desa Giri Jaya cukup jauh dari keramaian kota. Orbitasi dari desa ini menuju ibu kota kecamatan $5 \mathrm{~km}$, dengan lama jarak tempuh menggunakan kendaraan bermotor sekitar 0,15 jam atau berjalan kaki sekitar 1 jam. Kemudian jarak ke ibu kota kabupaten adalah $63 \mathrm{~km}$, dengan lama jarak tempuh 3 jam menggunakan kendaraan bermotor.

Asal-usul adanya Giri Jaya Padepokan memiliki kisah tersendiri dan terjadi pada waktu yang telah lama. Giri Jaya pada tahun 1827, di kaki Gunung Salak sebelah selatan dengan ketinggian $900 \mathrm{~m}$ dpl, di hutan belantara, pada waktu itu ada seorang yang menamakan Eyang Kulon. Nama aslinya adalah Eyang Abu Shohih. Beliau bertapa, memohon kepada sang Pencipta bumi alam, untuk keselamatan negara dan bangsa, karena pada waktu itu negara sedang dijajah oleh Belanda.

Selama tiga tahun setengah Eyang Kulon berada di kaki Gunung Salak. Kemudian datang seseorang dari "Mangku Negara" Surakarta, yang menamakan dirinya Eyang Wetan, bernama Ama Santri. Beliau mengajak pindah Eyang Kulon dari kaki Gunung Salak ke bawah, yang kurang dari $1 \mathrm{~km}$ dari tempat semula. Persahabatan mereka terus berlanjut. Eyang Wetan ada di sebelah timur, dan Eyang Kulon ada di sebelah barat. Kemudian sebagai tanda persahabatan mereka, ditanamlah dua pohon jambu samarang, yang ditanam kira-kira pada tahun 1831. Sampai saat ini pohon jambu tersebut masih berdiri tegak dan dirawat oleh anak cucu buyut beliau.

Tak lama kemudian Eyang Kulon membangun rumah besar yang disebut Rumah Kidul. Eyang Kulon mempunyai putra-putri, yaitu : R. Muhamad Kentar, R. Wiratmaja, R. Bai, R. Anjung, dan Ra. Ningrum. Mulai saat itu banyak orang yang datang kepada Eyang Kulon, meminta syariat keberkahan, karena Eyang Kulon itu seorang kiai. Bekas beliau bertapa sekarang disebut "Pondok Gusti" dan sampai saat ini masih ada, bahkan sudah dibangun.

Cucu Eyang Kulon dari anaknya yang bernama R. Wiratmaja, bernama Rd. Dadang. Rd. Dadang dari usia 6 tahun mengikuti jejaknya, yaitu sering bertapa di pasir-pasir dan kebun-kebun. Pasirnya kini dikenal sebagai Pasir Manglid di Desa Cidahu dan kebunnya yang kini disebut Desa Giri Jaya, Kecamatan Cidahu, Kabupaten Sukabumi.

Pada tahun 1929, Eyang Wetan atau Ama Santri wafat dan Rd. Dadang suka bernaung di bangunan makam tersebut. Waktu itu Eyang Kulon memanggil cucunya, Rd. Dadang yang masih berumur 9 tahun. Pada saat itu Rd. Dadang disuruh memainkan Wayang Golek, menghibur para tamu yang datang dan warga masyarakat. Padahal sang cucu tidak tahu menahu atau tidak pernah belajar mewayang, bahkan tidak tahu nama wayang, suara wayang, apalagi lelakon wayang. Rd. Dadang adalah seorang penurut kepada eyangnya, ia menyatakan sanggup untuk melaksanakan tugas tersebut dan memohon doa restu dari eyangnya. Timbul keajaiban, dalam perasaannya, eyangnya masuk dalam dirinya, sehingga pelaksanaan pergelaran 
Wayang Golek tersebut sukses. Rd. Dadang pun terkenal pada saat itu dengan sebutan "Dalang Cilik" dan banyak yang memanggil ke tempattempat hajat di berbagai daerah.

Pada tahun 1942, Eyang Wiratmaja wafat, kemudian kepemimpinan di Giri Jaya diteruskan oleh Rd. Dadang. Program pertama Rd. Dadang adalah : Seren Taun Nampak Taun, Mapag Tahun Baru Hijriyah setiap tahun; Mauludan ditambah khitanan massal; dan mengajak warga masyarakat untuk membangun jalan dari Giri Jaya sampai Cibaregbeg, sehingga kendaraan menuju Giri Jaya bisa sampai ke tempat.

Sejak itu berdatanganlah orangorang dari berbagai daerah menuju Giri Jaya untuk mendukung pelaksanaan Seren Taun dan Mauludan, seperti dari Kabupaten Sukabumi, Bogor, Bekasi, dan Tangerang. Rd. Dadang kemudian menambah pembangunan, berupa : rumah kidul 'rumah besar', pendopo, dapur umum, ruang penginapan tamu, dan merapihkan halaman-halaman.

Pada tahun 1987, Rd. Dadang wafat dan meninggalkan dua orang putra, yaitu RDN Ruyat dan R. Darma. Budaya tersebut di atas dilanjutkan oleh RDN Ruyat, bahkan dukungan dari warga masyarakat setempat dan dari luar daerah semakin banyak. Giri Jaya pun kemudian dinamakan Padepokan Giri Jaya. Peninggalan leluhur yang hingga kini masih terpelihara dengan baik adalah benda pusaka (keris-keris) dan Aksara Jawa Kuno 400 halaman, yang rencananya akan dijabarkan.

Sekitar satu sampai dua tahun belakangan ini, para sesepuh merasa penamaan Padepokan Giri Jaya tidak berkah. Banyak warga yang ngaheulakeun nu sunah, ninggalkeun nu wajib 'mendahulukan yang sunah, meninggalkan yang wajib'. Akhirnya kemudian, RDN Ruyat bersama para sesepuh lainnya pada tahun 2007 memutuskan untuk mengubah susunan nama tersebut menjadi Giri Jaya Padepokan. Penggantian nama tersebut diumumkan pada saat Upacara Seren Taun di hadapan para peserta upacara, yang datang dari berbagai daerah.

Mata pencaharian utama yang diusahakan oleh penduduk Giri Jaya Padepokan adalah dalam bidang pertanian, perikanan, dan peternakan. Pertanian merupakan mata pencaharian utama mereka dengan bercocok tanam di sawah dan ladang. Dengan persediaan air yang cukup dapat mengairi sawah sepanjang tahun, sehingga daerah tersebut tidak mengalami kekeringan. Teknik pengairan dilakukan secara sederhana dengan mengalirkan air melalui solokan-solokan 'selokan-selokan' kecil. Untuk menyimpan padi mereka, terdapat lumbung padi atau leuit, yang beberapa dimiliki warga secara pribadi.

Pola pemukiman Giri Jaya Padepokan tertata dalam sejumlah bangunan yang terdiri atas : sejumlah rumah, Bumi Ageung, Bale Kambang, Pancak Saji, Leuit Padi, Saung Kohkol, Tampian Panengah (tempat pemandian para tamu), Lisung Warga, Dapur Umum, Leuit dan Saung Lisung, Paseban, Kesekretariatan, Mesjid, Tempat Pancak Saji, panggung hiburan, tempat istirahat tamu, kamar mandi/tampian. Berikut ini denah tata letak bangunan-bangunan tersebut. 
Gambar 1

Denah Pola Pemukiman Giri Jaya Padepokan

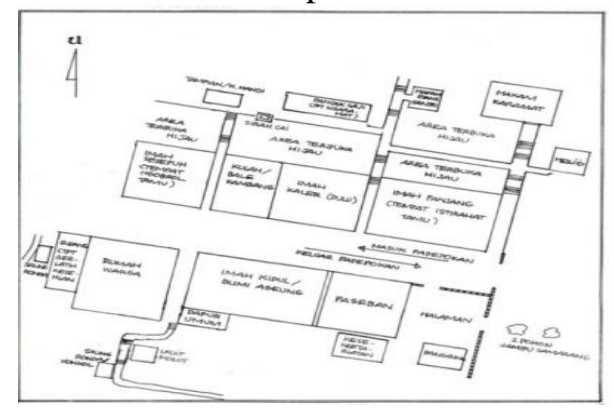

Rumah-rumah warga terdapat di sekitar Leuit, Saung Ronda, dengan kontur tanah menurun atau berundakundak. Perumahannya cukup padat. Di antara bangunan-bangunan rumah terdapat beberapa leuit ( 3 buah) milik warga yang masih dipakai dan terpelihara dengan baik. Bangunanbangunan rumah warga ada yang permanen dengan model seperti rumahrumah di perkotaan, sebaliknya ada pula yang masih tradisional, berdinding anyaman bambu dengan pencahayaan yang kurang baik.

Kemudian dengan adanya komplek makam para leluhur yang disebut makam keramat, penduduk pun sering melakukan ziarah ke kuburan karuhunnya. Dalam makam keramat terdapat makam Eyang Abu, Eyang Wirat, Eyang Dadang, Eyang Aon, dan Eyang Entang. Selain pada hari-hari biasa, ziarah pun dilakukan pada harihari tertentu, terutama pada Hari Raya Idulfitri, Idul Adha, Muharam, dan Maulud.

Kuburan-kuburan yang dianggap keramat itu tidak saja dikunjungi warga setempat, tetapi juga oleh peziarah dari daerah lain, seperti : Sukabumi, Bogor, Tangerang, Bekasi, dan Karawang. Tradisi ziarah atau berkunjung ke tempat-tempat yang keramat ini mungkin merupakan upacara yang pernah dilakukan oleh nenek moyang, ketika mereka masih menganut kepercayaan lama (buhun). Hal ini berkaitan dengan banyaknya peninggalan yang tampaknya bertradisi Megalitik, seperti : bangunan batu berundak atau punden, yang terletak di Pasir Karamat, Batu Kapak, Batu Julang, Batu Karut, dan lain lain.

Berbicara tentang budaya leluhur yang kini masih dipertahankan oleh pemimpin padepokan beserta warga masyarakatnya, berarti berbicara budaya yang telah dipertahankan oleh empat generasi (uyut, eyang, bapa, dan Abah). Ada amanah dari leluhur, bahwa dalam setahun sekali harus diadakan upacara adat tradisi, seperti Seren Taun Nampa Taun atau Sedekah Bumi, Tawasul, Mapag Taun Baru Hijriah, dan Ruatan Bumi.

Keempat upacara ini ada maksud serta tujuan yang telah ditentukan, baik lahiriah maupun batiniah. Upacara Seren Taun Nampa Taun atau Sedekah Bumi yang dilaksanakan pada bulan Muharam adalah upacara setelah panen padi, yang merupakan penyataan syukur para petani atas segala rahmat dan nikmat yang diberikan Yang Maha Agung, serta doa dari para leluhur Giri Jaya di Pondok Gusti, berkenaan dengan keberhasilan panen padi yang mereka tunggu-tunggu selama semusim. Upacara Tawasul. Dalam bahasa buhunnya, tawasul adalah tansil atau ngarekes, yang artinya nyuhunkeun/meminta/matur nuwun jaluk Gusti Agung. Adapun yang diminta kepada Yang Maha Agung adalah agar mereka mulus sareng rahayu, berkah selamat, subur makmur lan jinawi gemah ripah. Mudah- 
mudahan negara dengan rakyat murah sandang lan pangan. Selanjutnya Upacara Mapag Taun Hijriah yaitu upacara syukuran menyambut tahun baru Islam. Upacara Ruatan Bumi sendiri, pada saat doa Ruatan Bumi, berkumpul bersama pada saat itu para sesepuh, ustadz, kyai, tokoh masyarakat, pemuda/i, dan keluarga besar para aparat. Pada hari Sabtu, jemaat berkumpul dan ngaramat atau membaca kisah Syekh Abdul Jaelani (wali). Setelah itu diadakan acara hiburan semalam suntuk dari para penyumbang, berupa kesenian Dangdut, Topeng, Wayang Golek, Jaipongan, Wayang Kulit, Dogdog Lojor, Reog, Rengkong, dan lain-lain. Acara diakhiri dengan berdoa bersama sesepuh dan para tokoh masyarakat.

Sebagai penganut agama Islam sekaligus warga yang kukuh pada ajaran-ajaran adat yang menjadi kekayaan spiritual mereka, warga masyarakat Giri Jaya memiliki sistem kepercayaan yang bersumber dari agama dan kepercayaan warisan leluhur mereka. Dari sistem kepercayaan tersebut lahirlah berbagai jenis upacara tradisional yang berkaitan dengan aktivitas pertanian dan peristiwa alam yang telah diterangkan di atas, serta upacara daur hidup (life cycle).

Salah satu upacara daur hidup adalah upacara kematian. Apabila seseorang meninggal dunia, maka pada malam harinya keluarga dan kerabat yang ditinggal mengadakan upacara tahlilan atau sedekahan untuk mendoakan arwah yang meninggal. Upacara ini dilakukan hingga malam ketiga, ketujuh, hari keempat puluh (matang puluh), hari keseratus (natus), dan setahun. Para tetangga membantu keluarga yang ditinggal, ketika almarhum sadugna, tahlilan hijina, tiluna, tujuhna, hingga opat puluhna. Mereka nyambungan dengan mengirim beras, acis sadugna 'pemberian uang ketika saat meninggalnya'. Pada saat natusna, orang jarang yang nyarambungan. Sesudah tujuhna, dilakukan ngajojoan pada malam Senin, malam Jumat, yaitu ngaos 'membaca Alquran', yang dipimpin seorang guru mengaji. Ketika almarhum sadugna, keluarga membuat nasi udang. Kemudian ketika ngajojoan, keluarga membuat aneka kue. Adapun pada hari tiluna, tujuhna, opat puluhna, biasanya keluarga membuat makanan berat untuk para tetangga yang tahlilan.

Kegiatan keagamaan lainnya yang dilakukan warga masyarakat adalah pada malam Jumat Kliwon, secara rutin setiap bulan diadakan syukuran massal berupa tahlilan dan sholawatan. Kemudian untuk menambah pengetahuan agama Islam, warga sering menghadiri ceramahceramah keagamaan yang diadakan secara berkala atau pada acara-acara keagamaan tertentu, misalnya pada acara Rajaban, Muharraman, dan Mauludan.

Selain pemimpin formal yaitu pimpinan kampung seperti ketua RT dan RW, yang dikukuhkan oleh pemerintah setempat dengan memperhatikan pilihan masyarakat, di Giri Jaya terdapat pemimpin nonformal. Pemimpin nonformal adalah seorang sesepuh adat yang karena pengetahuannya, kharismanya, dan wibawanya, dihormati dan disegani masyarakat sekitar. Sesepuh adat di 
Giri Jaya, tepatnya sesepuh adat di Giri Jaya Padepokan adalah RDN. Runayat atau dikenal dengan panggilan Abah. Dalam rapat-rapat kampung yang dipimpin oleh pemimpin formal, Abah sering diundang secara khusus. Selain itu, di Kampung Giri Jaya pun ada beberapa orang yang disebut dengan Jaga-Jaga, di antaranya : Jaga Baya, Jaga Wana, Jaga Tirta, Jaga Aqidah. Masing-masing Jaga tersebut mempunyai tugas sendiri-sendiri dan beranggotakan banyak orang. Mereka yang mendapat tugas sebagai Jaga tersebut diangkat oleh warga lingkungan setempat dan mendapat restu dari Kadisbudpar Provinsi Jawa Barat. Para Jaga ini sering dimintai pendapat dan nasihat oleh warga dan pemimpin formal dalam memecahkan suatu masalah.

Jaga Baya atau Jaga Reksa (ngareksa/menjaga keamanan) mempunyai tugas, di antaranya menjaga keamanan manakala datang musibah yang tidak terduga, seperti kebakaran. Jaga Baya juga bertugas menjaga Paseban.

Jaga Wana yaitu orang yang menjaga wana atau leuweung (bahasa Sunda) 'hutan'. Salah satu kegiatannya adalah mengadakan penyuluhanpenyuluhan tentang lingkungan hidup, seperti imbauan tidak merusak hutan agar terhindar dari bencana longsor. Informasi disampaikan melalui ceramah-ceramah pada saat sembahyang Jumat. Menurut para sesepuh, pada syariatnya agar gunung tidak gundul dilakukan penanaman kembali berupa penghijauan. Kemudian pada hakikatnya, ada acara ritual untuk menjaga agar gunung tidak meletus, yaitu Ngaruwat Gunung dengan menyediakan sesajen, berupa embe hitam 'kambing hitam' sebagai tolak bala. Di sana ada ritual tolak bala, yang ditujukan ke Sanghyang yang menduduki gunung. Yang menjaga keselamatan gunung adalah Hanoman Putih (dalam cerita wayang). Tolak bala seperti ini pun dilakukan ketika datang musim kemarau, yang mengakibatkan persediaan air penduduk menjadi kering. Di tempat keramat, embe hideung dijadikan sebagai tumbal.

Jaga Tirta yaitu orang yang menjaga air, dalam artian menjaga keberadaan air, yang merupakan kebutuhan warga masyarakat, baik yang berhubungan dengan kebutuhan kehidupan sehari-hari, maupun kebutuhan dalam pertanian. Tugas mereka mulai dari menjaga sumber mata air, solokan-solokan, hingga mengatur pembagian air melalui saluran-saluran untuk warga masyarakat.

Adapun Jaga Aqidah adalah orang yang menjaga serta membina aqidah warga masyarakat agar terhindar dari perbuatan-perbuatan yang tidak baik dan melanggar aturan agama.

Hingga saat ini di wilayah Giri Jaya Padepokan dan sekitarnya terdapat beragam jenis kesenian tradisional, seperti Reog, Calung, Kendang Penca, Degung, Kacapi Suling, Tayuban, Tari Serimpi, Wayang Golek, Topeng, dan lain lain. Fungsi kesenian selain untuk hiburan, kemungkinan dulu digunakan pula untuk mengiringi upacara sakral. Keterampilan warga untuk menabuh instrumen karawitan biasanya diperoleh dari orang tuanya, yang diturunkan secara turun temurun. Pada umumnya ragam kesenian tersebut ditampilkan pada kesempatan hajatan pernikahan, 
khitanan, dan hari-hari raya nasional, seperti Hari Ulang Tahun Kemerdekaan RI.

Kecintaan mereka akan seni tradisional, berhubungan erat dengan keberadaan seni tradisional yang telah dimiliki leluhur - sejak jaman Eyang Santri, yaitu Wayang Kulit yang berbahasa Jawa. Keahlian Seni Wayang Kulit ini kemudian turun ke orang tua Abah, Eyang Dadang. Selanjutnya darah seni mengalir ke keturunan Eyang. Anak-anaknya belajar dan berguru sendiri. Kesenian Wayang Kulit tampil dalam setiap Upacara Seren Taun.

Selain bentuk kesenian tradisional di atas, di Giri Jaya Padepokan pun terdapat seni bangunan peninggalan leluhur. Seni bangunan tersebut tampak pada benteng-benteng atau dinding batu (stone wall's), yang disusun rapih pada sawah-sawah, tebing-tebing, dan pada bangunan berundak. Keterampilan menyusun batu-batuan, yang merupakan salah satu ekspresi seni ini pun terlihat pada beberapa kuburan bercorak Islam. Tanah yang menutupi kuburan ditata dengan batu-batu kecil, beratap rumah tradisional 'parahu kumereb' atau perahu tengkurap/ngajahul. Bentuk atap ini memiliki empat buah bidang atap. Bentuk atap rumah tradisional parahu kumereb ini sering juga disebut bentuk atap jubleg nangkub.

Penduduk sekitar percaya, bahwa tidak saja rumah-rumah yang perlu diberi atap pelindung, tetapi kuburan pun di atasnya perlu diberi semacam atap pelindung, agar tidak kena panas dan hujan. Seni hias pada kuburan yang demikian mungkin hanya terdapat di wilayah Giri Jaya. Seni bangunan dan seni hias yang diungkapkan di atas diperkirakan adalah sisa-sisa tradisi megalitik kuburan yang diwarisi dan diteruskan oleh keturunannya hingga sekarang.

\section{Arsitektur Tradisional di Giri Jaya Padepokan Kabupaten Sukabumi}

Jenis-jenis bangunan yang berarsitektur tradisional di Giri Jaya Padepokan, yang hingga kini masih berdiri dan terpelihara dengan baik adalah Bangunan Tempat Tinggal, Tempat Berkumpul/Musyawarah, dan Tempat Menyimpan.

\section{a. Bangunan Tempat Tinggal}

Rumah merupakan tempat tinggal, tempat sebagian besar praktekpraktek domestik dilakukan dan keberadaan diri terekspresikan. Dalam bahasa Sunda rumah disebut imah, bumi. Rumah yang berarsitektur tradisional di Giri Jaya Padepokan, yang hingga kini masih terpelihara dengan baik dan selalu diupayakan untuk dijaga bentuk keasliannya adalah Imah Kidul.

Imah Kidul sudah ada sejak 4 generasi yang lalu. Imah Kidul yang awalnya bernama Rumah Kidul dibangun oleh Eyang Abu Sholih, sebagai generasi pertama. Eyang Abu Sholih menamakan dirinya sebagai Eyang Kulon, sudah tinggal di kaki Gunung Salak, di daerah Giri Jaya sekarang sejak tahun 1827. Sebelum membangun rumah, beliau bersahabat dengan pendatang dari "Mangku Negara" Surakarta, yang bernama Ama Santri dan menamakan dirinya sebagai Eyang Wetan.

Persahabatan mereka terus berlanjut. Eyang Wetan yang kemudian bergelar Kyai Santri ada di sebelah 
timur, dan Eyang Kulon yang bergelar Kyai Aboe Bakar ada di sebelah barat. Kemudian Eyang Kulon membangun rumah besar yang disebut Rumah Kidul. Selain Rumah Kidul beberapa lama kemudian dibangun Bumi Kaler. Bumi Kaler ditempati oleh Embah Wiratmaja, putra Eyang Kulon. Namun pada tahun 1962, Bumi Kaler mengalami kebakaran hingga habis.

Rumah pertama Eyang Kulon ini selain mendapat sebutan Imah Kidul, warga pun mengenalnya dengan sebutan Bumi Kidul, Imah Ageung, atau Bumi Ageung. Bentuk Imah Kidul adalah bentuk rumah tradisional, yang memiliki ciri peninggian lantai atau berbentuk panggung. Walaupun ciri rumah panggung yaitu kolong, dari arah depan, samping kiri, dan belakang rumah tak nampak karena sudah ditutup tembok, bentuk tatapakan masih terlihat jelas di samping kiri dan belakang rumah. Kolong rumah sendiri dapat dilihat pada rumah bagian samping kiri.

Dalam arsitektur tradisional Sunda, Imah Kidul memiliki gaya bukaan pongpok, yaitu pintu muka menghadap arah bagian pendek atap rumahnya. Adapun bentuk atapnya menggunakan suhunan panjang dengan memakai jure. Atap terbuat dari genting; kayu-kayu bangunannya berjenis kayu rasamala, yang banyak ditemukan di lingkungan sekitar; dinding dari anyaman bambu ukuran besar 'giribig' dan kayu, lantai dari kayu, jendela bukaan dua dan berkaca, serta pintu yang bukaan dua juga. Warganya sendiri menyebutkan Imah Ageung meniru model bangunan Jawa, dengan ciri ada kembang karton di atasnya.

Sesuai dengan amanah leluhur, bahwa bentuk Imah Kidul ini harus dijaga keasliannya. Amanahnya, jika rusak tiang satu, maka ganti yang satu itu. Jadi tidak boleh dirubuhkan. Namun perkembangan selanjutnya, setelah beberapa generasi, terdapat beberapa perubahan. Bagian yang telah mengalami perubahan seiring dengan dibangunnya Paseban adalah ditutupnya kolong dengan tembok dan pemasangan keramik pada ruang tamu di belakang.

Berikut ini bagian-bagian rumah: golodog, kolong, tatapakan, tihang, dingding, panto, jandela, lalangit, suhunan, hateup, dan lincar disertai dengan fungsi masing-masing bagian tersebut.

Golodog adalah tangga untuk memasuki Imah Kidul, yang terbuat dari tembok bata dengan jumlah anak tangga satu buah. Fungsi golodog ini sebagai penghubung lantai rumah dan lantai luar di pintu masuk Imah Kidul.

Kolong adalah ruang kosong di bawah lantai rumah yang berbentuk panggung. Kolong pada Imah Kidul memiliki ketinggian sekitar $45 \mathrm{~cm}$. Kini kolong di bagian samping kiri dan belakang dinding rumah telah ditutup dengan tembok, namun bentuk tatapakan masih jelas terlihat. Akan halnya kolong di sebelah kiri dinding rumah tidak ditutup. Dinding kiri rumah berhubungan langsung dengan bangunan tambahan untuk dapur umum, tempat menjemur pakaian, dan sebagainya.

Tatapakan adalah penahan dasar dari tiang Imah Kidul, yang terbuat dari batu alam, yang dibentuk menyerupai jubleg 'alat untuk menumbuk, berlubang satu'. Bentuknya persegi dengan badan mengerucut ke bawah, menyerupai limas segi empat terpancung terbalik. Ketinggian tatapakan 
ini sekitar $45 \mathrm{~cm}$ dengan lebar bagian bawahnya sekitar $20 \mathrm{~cm}$ dan lebar bagian atas sekitar $17 \mathrm{~cm}$, dan langsung menyangga pananggeuy Imah Kidul.

Gambar 2

Kolong bertembok dengan tatapakannya.

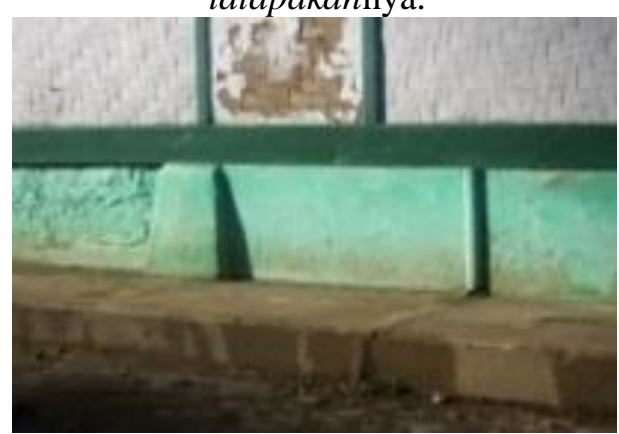

Sumber : Data Penelitian 2009

Tihang atau tiang adalah penyangga atap Imah Kidul, yang terbuat dari kayu berbentuk segi empat. Selain untuk menyangga, tihang ini pun untuk menempelkan dindingdinding Imah Kidul yang terbuat dari bilik 'anyaman dari bilahan bambu yang tipis'. Bilahan bambu tipis pada anyaman bilik yang digunakan ukuran lebarnya sekitar $3 \mathrm{~cm}$.

Dingding atau dinding adalah bagian dari Imah Kidul, yang berfungsi sebagai penutup bagian luar dan penutup bagian dalam. Penutup bagian luar, yang memisahkan antara ruangan dengan alam sekitar. Adapun penyekat bagian dalam yang memisahkan antarruangan dalam rumah. Dingding ini terbuat dari bilik atau papan kayu dan menempel langsung pada tihang imah. Dingding imah bagian belakang seluruhnya terbuat dari papan yang disusun vertikal.
Gambar 3

Dingding yang terbuat dari bilik dan papan kayu.

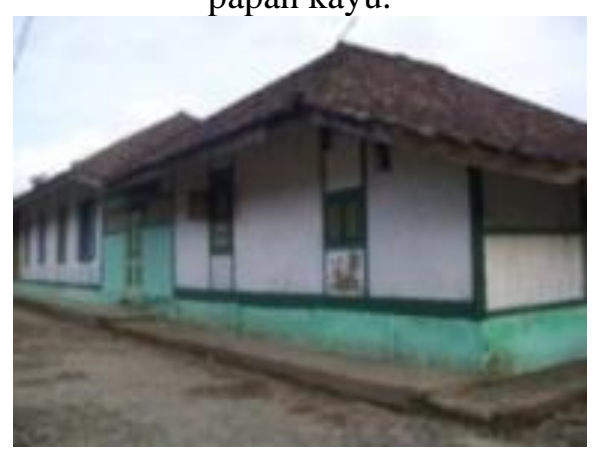

Sumber : Data Penelitian 2009

Panto atau pintu adalah penutup lubang untuk jalan masuk dan keluar rumah. Panto pada Imah Kidul ini ada yang bukaan satu, ada pula yang bukaan dua. Yang bukaan satu terbuat dari papan kayu yang disusun vertikal. Ada pun panto yang bukaan dua, sepertiga bagian daun pintunya (bagian bawah) terbuat dari papan kayu; dua per tiga bagian (bagian atas) terbuat dari lempengan-lempengan kayu berukuran lebar sekitar $8 \mathrm{~cm}$ dan panjang sekitar lebar daun pintu, yang disusun sedemikian rupa vertikal ke atas, sehingga bentuk daun pintunya berjalosi rapat. Di atas panto ada kaca untuk penerangan dan ventilasi 'lubang angin'. Pintu bukaan dua digunakan sebagai pintu masuk dari Ruang Tamu dan Ruang Paniisan di depan ke Ruang Tawasulan; di belakang ke Ruang Tamu, di sisi kanan dan kiri rumah menuju luar rumah.

Jandela atau jendela adalah lubang cahaya dan pertukaran udara dari dalam ke luar ruangan atau sebaliknya di dingding yang bisa ditutup dan dibuka. Jandela Imah Kidul selain bentuk daun jendelanya bukaan dua dan tinggi, juga memiliki 
dua daun jendela (dengan masingmasing bukaan dua). Daun jendela pertama dari arah dalam berkaca, dan jendela kedua terbuat dari lempengan kayu yang disusun vertikal memenuhi daun jendelanya. Jenis jendela seperti ini disebut duduk jandela, yaitu jenis gaya arsitek Vernakuler tahun 1930-an. Kusen jendela memiliki kekhasan tersendiri. Kusen vertikalnya memanjang dari batas lalangit hingga ke lincar rumah. Jendelanya yang tinggi memungkinkan sinar matahari dan udara bersih masuk leluasa ke dalam rumah.

Lalangit adalah penutup langitlangit rumah yang terpisah dari dinding, tetapi menempel pada dasar rangka atap. Lalangit Imah Kidul terbuat dari bilik.

Suhunan adalah atap bangunan paling atas dari Imah Kidul yang terbuat dari sebatang kayu atau balok berbentuk segi empat tanpa sambungan, membentang dari ujung puncak imah. Fungsinya untuk tempat dudukan wuwungan 'bubungan rumah'. Suhunan Imah Kidul berbentuk suhunan panjang dengan memakai jure atau dikenal dengan gaya bukaan pongpok. Gaya ini meletakkan pintu muka menghadap ke arah bagian pendek atap rumahnya. Dalam hal ini Imah Kidul mempunyai pintu muka menghadap ke arah timur, dimana merupakan arah bagian pendek dari atap rumahnya.

Hateup adalah atap rumah. Hateup Imah Kidul terbuat dari genting. Pada palang tinggang atau resplang menggunakan ornamen kembang karton. Kembang karton ini beragam hias flora (bunga).
Gambar 4

Resplang dengan ornamen kembang karton.

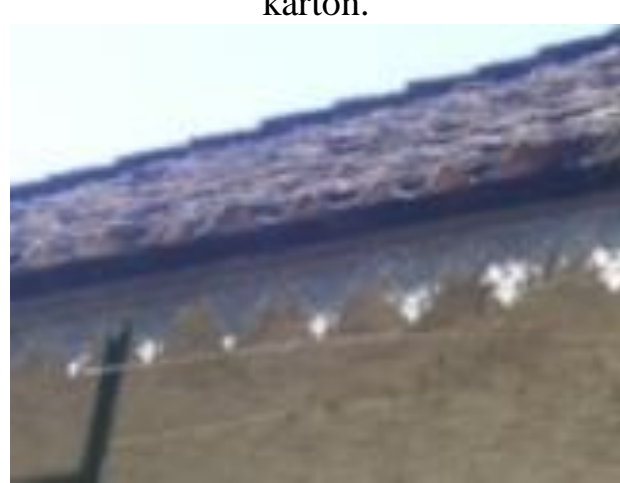

Sumber : Data Penelitian 2009

Lincar adalah bagian rumah panggung, yang gunanya untuk menjepit dinding di sekeliling bagian bawah rumah. Lincar di Imah Kidul terbuat dari kayu pipih setebal $1 \mathrm{~cm}$ dan lebar sekitar $15 \mathrm{~cm}$.

Gambar 5

Denah Imah Kidul

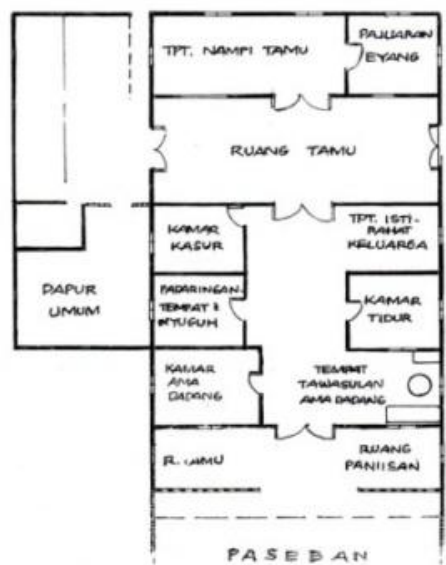

Tata ruang Imah Kidul terdiri atas Ruang Tamu, Ruang Paniisan, kamar tidur, Tempat Tawasulan, Ruang Padaringan, Kamar Kasur, tempat istirahat keluarga, Tempat Nampi Tamu, Pajuaraan Eyang, Dapur Umum. Berikut ini denah Imah Kidul. 
Ruang Tamu dan Ruang Paniisan terletak di bagian depan Imah Kidul, tanpa sekat tertutup dan berhubungan langsung dengan Paseban. Dulunya, sebelum ada penambahan bangunan Paseban, ruang ini merupakan tepas atau emper. Sesuai dengan fungsinya sekarang, dulu pun digunakan untuk menerima tamu atau tempat istirahat (paniisan).

Ruang Tamu berada di sebelah kiri dari pintu masuk. Ruangan ini terbuka tanpa penyekat tertutup. Dengan Paseban hanya dibatasi penyekat terbuat dari papan dan sarigsig kayu yang dibentuk sedemikian rupa di sebelah kiri dan kanan. Pada Ruang Tamu ini terdapat dua buah jendela dengan masingmasing berdaun jendela bukaan dua. Ruang Tamu ini fungsinya untuk menerima para tamu yang berkehendak melakukan tawasulan atau ada kepentingan lain.

Dalam Ruang Tamu hanya terhampar tikar untuk duduk para tamu. Sementara itu di dinding terpasang tiga buah lukisan karya Eyang Abu sendiri (lihat gambar). Lukisan-lukisan ini berupa gambar kendaraan Nabi Muhammad Saw. ketika Isra Miraj, Bouraq; dan tokoh pewayangan Jatayu. Peninggalan Eyang Abu tak hanya itu, banyak surat-surat dari para jemaah yang ditujukan kepada Eyang Abu, yang hingga kini masih tersimpan dengan baik oleh Abah Ruyat. Selain itu, Eyang Abu pun memiliki naskah kuno tertanda tahun 1827 sebanyak 11 lembar bertanda emas Kerajaan Surakarta. Hingga kini naskah tersebut belum ada yang sempat dan bisa menerjemahkan.

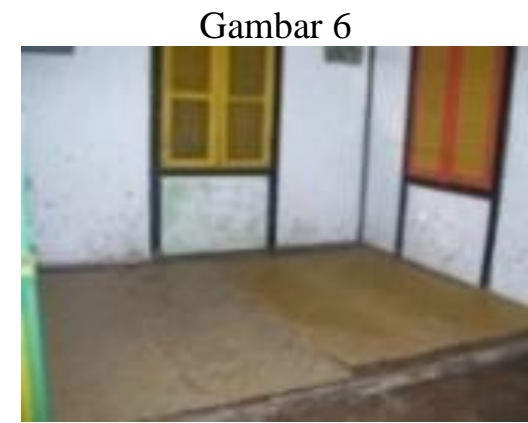

Ruang Tamu beralaskan tikar pandan.

Gambar 7

Lukisan Bouraq dan Jatayu karya Eyang Abu

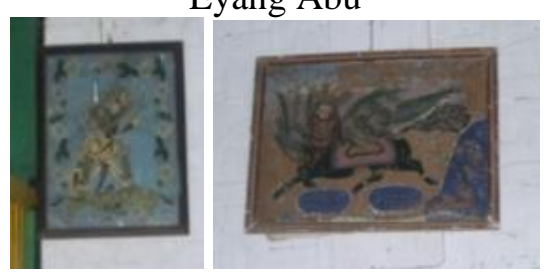

Sumber : Data Penelitian 2009

Ruang Paniisan berada di sebelah kanan pintu masuk. Para leluhur dulu menggunakan Ruang Paniisan ini untuk tempat istirahat dan menikmati segarnya alam pegunungan.

Gambar 8

Ruang Paniisan dengan barang-barang peninggalan leluhur.

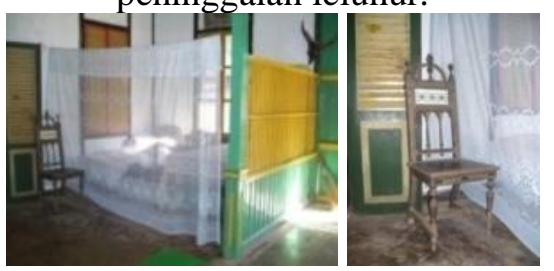

Sumber : Data Penelitian 2009

Kini setelah Paseban dibangun, di ruangan tersebut diletakkan satu buah kursi malas terbuat dari rotan, satu buah kursi tamu, dan satu buah kursi makan berukir dengan ragam hias flora (bunga), yang kesemuanya sudah berusia lama. 
Gambar 9

Barang-barang yang ada di Ruang Tawasulan
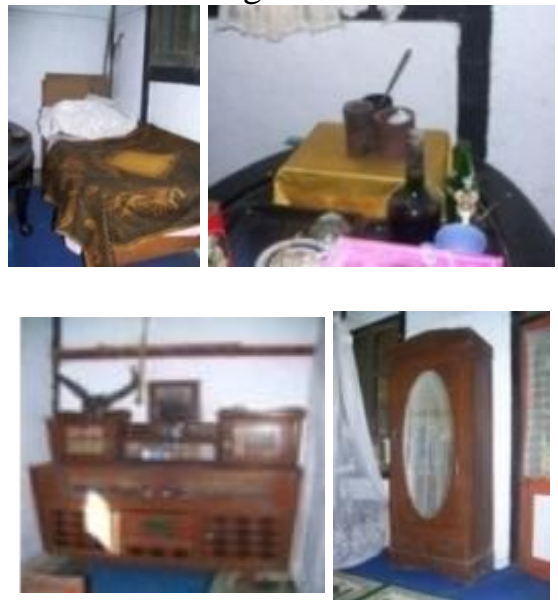

Sumber : Data Penelitian 2009

Dari Ruang Tamu dan Ruang Paniisan kemudian melalui pintu bukaan dua, didapati ruangan-ruangan yang berderet di sebelah kiri dan kanan, saling berhadapan. Langsung di sebelah kanan terdapat Ruang Tawasulan. Tawasul adalah tansil atau ngarekes, yang artinya memohon kepada Yang Maha Agung agar mendapat kelancaran, keselamatan, kesuburan, dan kemakmuran dalam kehidupan di dunia. Dalam ruangan ini, orang-orang bergantian untuk melaksanakan tawasulan dengan dipimpin oleh sesepuh Giri Jaya Padepokan.

Ruangan ini beralaskan karpet dan tempat sesepuh menerima tawasulan dialasi dengan sejadah. Dalam ruangan ini terdapat lemari pakaian, tempat tidur kecil, meja bundar tempat sesajen disajikan, tekas 'lemari kaca' atau bupet peninggalan leluhur. Selain itu, ruangan ini memiliki dua buah jendela, yang masing-masing berdaun jendela bukaan dua. Satu jendela menghadap ke luar arah utara, satu lagi berbatasan langsung dengan Ruang Paniisan. Sama seperti Ruang Paniisan, ruangan ini pun diberi gordein tipis warna putih.

Bersebrangan dengan Ruang

Tawasulan adalah kamar tidur Ama/Abah Dadang, leluhur generasi ketiga. Kamar ini tidak ditempati oleh keluarga. Adapun kamar tidur keluarga ada di seberangnya, bersebelahan dengan Ruang Tawasulan.

Bersebelahan dengan kamar tidur Ama Dadang adalah Ruang Padaringan. Ruang Padaringan ini adalah ruangan tempat menyimpan beras. Selain tempat menyimpan beras, ruang ini pun digunakan untuk ritual nyuguh yang dilakukan Ibu N, putri paling besar Abah Ruyat, yang tinggal di Imah Kidul. Ibu $\mathrm{N}$ sejak kecil diambil oleh Eyang Dadang dan Babu Oneng (Mimih), sebagai kakek neneknya untuk tinggal bersama di Imah Kidul. Hingga kini, kemudian Ibu $\mathrm{N}$ dipercaya untuk tinggal di Imah Kidul, sekaligus menjaga dan merawatnya.

Ritual nyuguh adalah ritual memberi suguhan/sesaji kepada para karuhun atau leluhur masyarakat Giri Jaya Padepokan. Ritual ini bermakna penghormatan kepada mereka dengan menyediakan apa yang menjadi kesukaan para leluhur, baik makanan, minuman, maupun yang lainnya. Sesaji yang disediakan adalah nasi congcot (nasi yang dibentuk kerucut dengan telur di atasnya), kopi pahit, kopi manis, teh tubruk, teh manis, rurujakan, roti, selasih, jeruk, air kembang 7 sampai 5 macam, kadang hahampangan, minyak wangi duyung, dan membakar dupa. Ritual nyuguh ini dilakukan rutin pada malam Senin 
hingga malam Jumat. Untuk malam Jumat biasanya sesajinya lebih komplet, terlebih jika ada maksad 'maksud/keinginan' dari keluarga.

Kemudian bersebelahan dengan Ruang Padaringan adalah Kamar Kasur. Kamar Kasur adalah ruangan tempat menyimpan kasur-kasur, sebagai persediaan manakala banyak tamu yang menginap pada pelaksanaan upacara-upacara adat di Giri Jaya Padepokan.

Berseberangan dengan Kamar Kasur terdapat ruangan dengan lantai yang lebih tinggi. Ruangan ini digunakan sebagai tempat istirahat atau berkumpul keluarga. Jendela yang tinggi dengan daun jendela bukaan duanya menjadikan ruangan ini tempat yang nyaman untuk beristirahat anggota keluarga.

Setelah Kamar Kasur dan ruang tempat istirahat, melalui pintu dengan daun pintu bukaan dua, akan tiba di Ruang Tamu di bagian belakang. Ruang Tamu ini terhitung lebih luas daripada ruang tamu yang ada di depan, hanya berupa ruang kosong. Awalnya lantai Ruang Tamu ini tidak menggunakan tegel. Namun atas beberapa pertimbangan, kemudian diperbaiki dan dilapisi dengan lantai keramik. Tentunya perubahan tersebut atas sepengetahuan dan seizin sesepuh adat.

Ruang Tamu ini gunanya untuk para tamu yang datang dan menunggu giliran bertemu dengan sesepuh adat untuk melakukan tawasulan. Mereka duduk di lantai dengan beralaskan tikar. Sementara di sebelah kanan ada pintu berdaun pintu dua menuju ke luar; dan di sebelah kirinya ada pintu berdaun pintu dua pula menuju ke bangunan samping kiri, tempat dapur umum, tempat menjemur pakaian, dan sebagainya.

Selanjutnya, dengan melalui pintu berdaun pintu bukaan dua, searah lurus dengan pintu ke ruang tengah sebelumnya, akan didapati Tempat Nampi Tamu. Di sini, para tamu diterima oleh sesepuh adat.

Tepat di sebelah kanan Tempat Nampi Tamu terdapat Ruang Pajuaran Eyang. Pajuaran dalam bahasa Sunda artinya tempat tidur. Ruang Pajuaran Eyang adalah ruang tempat tidur Eyang Abu/Ama Abu. Di dalamnnya terdapat tempat tidur, peti berisi pakaianpakaian kerajaan Ama Abu, meja sajen, dan pakarang-pakarang 'senjatasenjata'. Secara berkala, pakaianpakaian Eyang Abu dibersihkan oleh Abah Ruyat. Hal itu untuk menjaga jangan sampai kena rinyuh 'rayap', bahkan sesekali dijemur.

Dari Ruang Tamu di belakang, melalui pintu bukaan dua di sebelah kiri dan menghadap arah selatan, akan berhubungan langsung dengan ruangan-ruangan untuk bagian belakang, seperti dapur, tempat menjemur pakaian, kamar pembantu, dan sebagainya. Ruangan-ruangan ini berada pada bangunan tambahan di sebelah kanan belakang Imah Kidul. Bentuk atap bangunan ini adalah suhunan jolopong, yang memanjang sejajar dengan atap Imah Kidul arah memanjangnya.

Salah satu ruangan yang disebut dapur merangkap menjadi Dapur Umum. Dapur Umum berada di sebelah kiri ketika keluar dari pintu bukaan dua. Dapur umum terhitung cukup besar, di dalamnya terdapat beberapa hawu 'tungku' untuk 
memasak, beberapa 'bale-bale' terbuat dari tembok untuk duduk mengolah masakan, tempat mencuci peralatan dapur. Sebagian lantai dapur ditembok dan sebagian lagi tidak. Dindingnya sebagian menggunakan papan kayu yang disusun vertikal hingga batas pamikul, sebagian lagi menggunakan bilik setengah badan dan bagian atasnya meggunakan jalosi hingga batas pamikul. Dapur umum ini tanpa lalangit, dibiarkan terbuka hingga jelas terlihat atap rumah.

Untuk memasak sehari-hari, Ibu menggunakan dapur ini. Baru, dalam kegiatan upacara-upacara adat yang melibatkan banyak orang, terutama kemudian yang terkait dengan masalah penyediaan konsumsi, maka Dapur Umum ini berfungsi, bahkan memegang peranan penting.

\section{Bangunan Tempat Berkumpul/Musyawarah}

Bangunan tempat musyawarah atau berkumpul di Padepokan Giri Jaya disebut Paseban. Paseban dibangun pada masa generasi ke-3, yaitu pada masa kepemimpinan RDN. Dadang. Hal itu dilakukan mengingat pada masa itu jemaat yang mengikuti berbagai upacara adat yang diadakan rutin setiap tahun, semakin banyak. Jadi beliau memperluas tempat untuk para jemaat, dengan kepentingannya dimana ada ritual adat, hiburan pun bisa dipentaskan di Paseban atau Pendopo. Paseban berasal dari kata pa-seba-an, seba (bahasa Kawi) yang berarti bakti, menyerahkan barang kepada raja atau kepala sebagai tanda berbakti. Jadi Paseban artinya tempat untuk menyerahkan barang sebagai bukti berbakti kepada Raja atau Kepala.
Paseban merupakan ruangan tambahan dari Imah Kidul, berupa aula berukuran $\pm 12 \times 9 \mathrm{~m}$, menyambung dari Ruang Tamu dan Ruang Paniisan. Bentuk bangunannya berdinding papan dan sarigsig kayu yang dibentuk sedemikian rupa sehingga membentuk ornamen dinding yang indah. Atap Paseban berbentuk limasan. Jumlah tiang di dalam ruangan Paseban ada empat buah. Suhunannya menghadap ke arah wetan 'timur', mengikuti bangunan yang sudah ada sebelumnya, yaitu Imah Kidul. Paseban menggunakan pintu di sekelilingnya, memiliki makna untuk memudahkan orang masuk dari arah manapun, dari daerah asal mana pun.

Bagian-bagian Paseban antara lain lantai, tiang utama, dinding, pintu, dan lalangit. Lantai Paseban dengan ketinggian yang disamakan dengan tinggi lantai Imah Kidul, ditutupi ubin hitam berukuran $20 \times 20 \mathrm{~cm}$. Pada permukaan lantai sepanjang dari pintu depan Paseban menuju pintu depan Imah Kidul digelar karpet warna hijau dengan lebar 2,5 m. Tiang utama (sasaka/saka guru) Paseban merupakan bagian bangunan yang sangat penting karena menyangga atap bangunan. Tiang terbuat dari kayu berbentuk segi empat berukuran 14 X $14 \mathrm{~cm}$.

Gambar 10 Suhunan Paseban

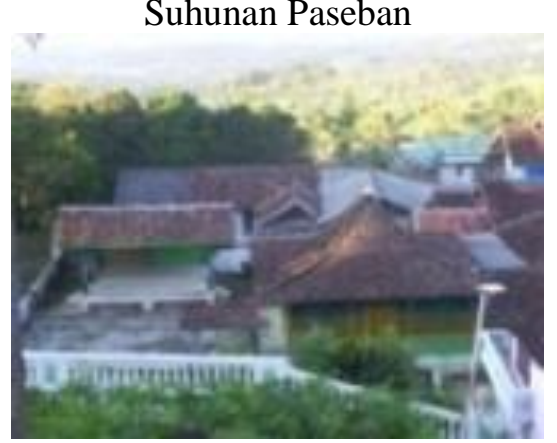


Sumber : Data Penelitian 2009

Jumlah tiang utama ini ada 14 batang, yang berguna pula untuk menempelkan dinding-dinding Paseban. Dinding Paseban bagian atas terbuat dari bilah-bilah papan kayu yang disusun vertikal dan setengah lingkaran di antara dua tiang (lihat gambar). Pada tiangnya diberi hiasan kayu segi empat yang berumpak membesar ke bagian atasnya. Pada tiang-tiang yang berhadapan langsung dengan Imah Kidul bagian depan, hanya terdapat dinding bagian atas yang sekaligus sebagai ornamen. Untuk memikul beban palang tinggang dibuat penguat dari batang kayu yang disambungkan dengan tiang utama dan diperkokoh dengan siku-siku dari besi yang berornamen flora. Pada tengah-tengah ruangan Paseban terdapat empat tiang yang menyangga lalangit Paseban, yang hanya dibuat bagian tengahnya saja.

Gambar 11

Salah satu sasaka di sudut bangunan

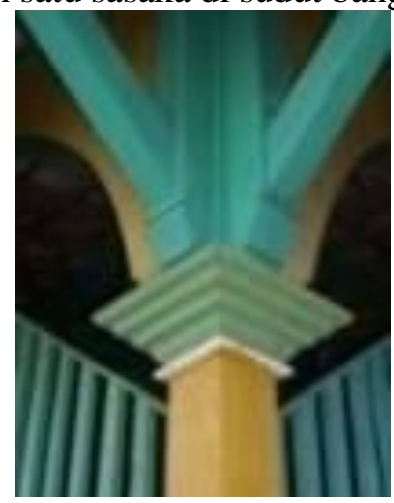

Gambar 12

Salah satu tiang utama

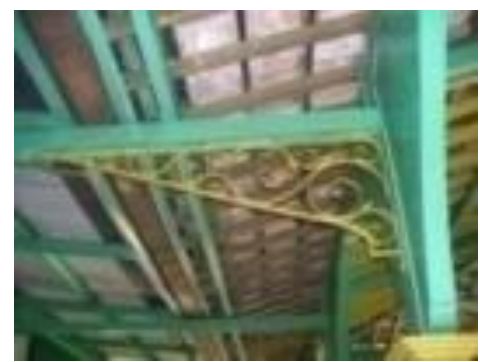

Gambar 13

Siku-siku dari besi berornamen flora

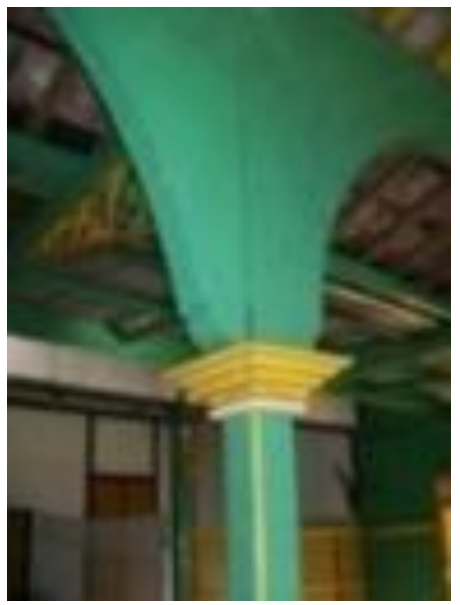

Sumber : Data Penelitian 2009

Telah disebutkan sebelumnya, bahwa dinding Paseban terbuat dari papan dan sarigsig kayu yang dibentuk sedemikian rupa, sehingga membentuk ornamen dinding yang indah. Dinding Paseban ini diperkuat oleh 2 tiang utama pada arah lebarnya, dan 3 tiang utama pada arah panjangnya, yang menahan pamikul rangka atas. Selain tentunya 4 tiang utama yang menyangga atap. Papan-papan kayu dengan lebar $15 \mathrm{~cm}$ dan tinggi $0,5 \mathrm{~m}$ disusun dalam posisi tegak dan rapat, diperkuat bagian bawah dan atas dengan jepitan papan selebar lebih kurang $10 \mathrm{~cm}$ sepanjang dinding. Kemudian bagian atasnya disambung dengan sarigsig kayu, yang dibentuk turih wajit di antara dua tiang (lihat 
gambar). Sarigsig terbuat dari kayukayu berukuran lebar lebih kurang 3 $\mathrm{cm}$ disusun dalam posisi tegak dengan jarak antara kayu yang satu dengan yang lain $3 \mathrm{~cm}$. Sarigsig diperkuat dengan bilahan kayu yang dipasang horizontal sepanjang arah panjang dan lebar dinding. Pintu Paseban berdaun pintu bukaan dua dengan ornamen mengikuti ornamen dinding. Pada bagian atas pintu terdapat lubang angin yang menggunakan jalosi dari besi.

\section{Gambar 14}

Dinding berornamen dan bagian pintu.

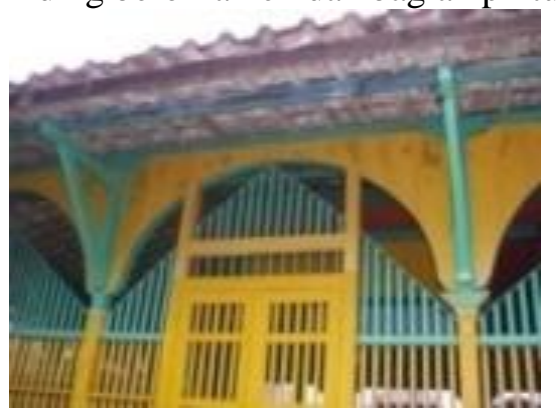

Sumber : Data Penelitian 2009

Sebagian besar Paseban tidak memakai lalangit. Hanya bagian tengahnya saja, berbentuk empat persegi yang menggunakan lalangit dan ditopang dengan empat tiang. Lalangit Paseban ini terbuat dari papan kayu yang disusun memanjang ke bagian atap pendeknya. Untuk memperkuat kedudukan lalangit, dipasang kayu penahan (lebar sekitar 5 $\mathrm{cm})$ yang disilangkan, sekaligus dijadikan sebagai ornamen atap (lihat gambar). Pada tengah-tengah persilangan kayu penguat tersebut dipasang hiasan berupa kayu berbentuk lingkaran yang diukir dengan ragam hias flora (bunga).
Gambar 15

Lalangit dengan hiasan ukiran kayu beragam hias flora.

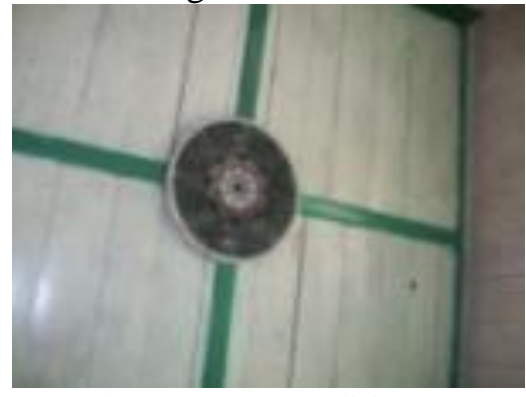

Sumber : Data Penelitian 2009

Fungsi Paseban sesuai dengan tujuan ketika dibangun oleh RDN Dadang, yaitu sebagai tempat penyelenggaraan berbagai acara ritual, bahkan untuk berbagai hiburannya pun dapat dilaksanakan di sana. Pembangunan Pesaben tersebut dengan pertimbangan, seperti yang telah diungkap di awal, bahwa dari tahun ke tahun jemaat yang mengikuti upacaraupacara tersebut semakin meningkat, sehingga kemudian dibutuhkan tempat yang lebih luas dan nyaman.

Perkembangan selanjutnya Paseban tidak hanya berfungsi sebagai acara-acara ritual saja, seperti acara Tawasulan, Seren Taun, Sedekah Bumi, Mapag Taun Hijriah, Ruatan Bumi, syukuran hari Jumat setiap bulan; juga untuk berbagai pertemuan yang berkaitan dengan kegiatan di Giri Jaya Padepokan, bahkan untuk menyimpan gamelan buhun. Usia gamelan ini sudah ratusan tahun, terdiri atas gending, rebab, gambang, saron 2, panerus, bonang, salikat, jengglong, dan goong. Gamelan ini untuk mengiringi pertunjukan Wayang Golek, kadang-kadang Kliningan, yaitu setahun sekali pada 12 Maulud. Para 
nayaganya sendiri sudah mulai dari tingkat generasi muda.

\section{Bangunan Tempat Penyimpanan}

Bangunan tempat menyimpan padi hasil pertanian pada masyarakat Sunda dinamakan Leuit. Semua Leuit pada dasarnya memiliki orientasi yang sama, yaitu bangunannya menghadap utara - selatan dengan pintu masuk di sebelah utara. Demikian pula halnya dengan Leuit yang ada di Giri Jaya Padepokan. Leuit milik adat sudah tidak berfungsi lagi, dalam artian kondisinya sudah rusak. Adapun beberapa Leuit yang ada adalah milik warga, jumlahnya ada tiga buah. Hingga kini leuit tersebut masih digunakan dan dimanfaatkan oleh pemiliknya untuk menyimpan padi. Kondisi leuit masih kokoh dan terpelihara dengan baik.

Bentuk dasar keseluruhan dari bangunan leuit adalah berupa bangunan panggung yang berdiri di atas enam atau delapan tiang. Pada leuit milik adat atau disebut Leuit Padi bentuknya seperti panggung biasa berdenah segi empat dengan atap berbentuk suhunan jolopong. Kolong leuit adat memiliki ketinggian sekitar $0,5 \mathrm{~m}$, sehingga di bawahnya bisa menyimpan kayu-kayu bakar. Dadampar atau tatapakan sebagai fondasi atau penahan pangkal dari tiang sekaligus menopang pananggeuy. Bahan batu dadampar terbuat dari batu alam atau batu padas yang keras kemudian dibentuk balok yang berdiri tegak dengan permukaan sisi atas lebih kecil daripada permukaan sisi bawah. Tiang leuit terbuat dari balok kayu berjumlah delapan buah. Dindingnya terbuat dari bilik. Iga yang terbuat dari papan sebagai penahan dipasang melintang di luar bilik.
Pemasangan iga ini hingga tiga buah untuk setiap dindingnya. Leuit ini dilengkapi dengan pintu yang terbuat dari papan kayu, dan jendela kecil. Atapnya sendiri terbuat dari genting.

Sementara itu leuit milik warga yang masih ada dan berfungsi ada tiga buah. Ketiga leuit ini sudah mengalami perubahan dalam hal bahan bangunannya. Bentuk dasar keseluruhan bangunan memang masih berpola pada bentuk leuit pada umumnya, yaitu berupa bangunan berlantai tinggi yang berdiri di atas enam atau delapan tiang, serta bentuknya semakin ke atas semakin besar. Kemudian berdenah segi empat dengan atap berbentuk suhunan limasan.

Bangunan leuit berlantai tinggi dengan ketinggian $\pm 30 \mathrm{~cm}$. Dadamparnya berupa tembok yang hampir memenuhi keliling lantai dasar leuit, hanya menyisakan kolong di bawah pintu masuk saja.Tiangnya berupa balok kayu dari jenis yang kuat, berjumlah delapan buah, berfungsi untuk menahan seluruh gaya berat bangunan itu sendiri pada rangka atap, serta untuk menempelkan dinding dan lincar atau cemped 'kayu-kayu penjepit dinding'. Tiang tidak terlihat dari luar, terlapisi dinding yang diperkuat dengan cemped kayu. Dinding Leuit terbuat dari giribig 'bilik dengan anyaman bilahan bambu yang besar'. Dinding bagian bawah, seukuran setengah badan orang dilapisi lagi dengan lembaran seng, yang diperkuat dengan cemped pada tiang utama Leuitnya. Pada batas seng dan bilik digunakan iga satu buah. Sementara itu cangkok, yaitu papan kayu yang dipasang mendatar di tepi bagian bawah Leuit 
berukuran sekitar $15 \mathrm{~cm}$, gunanya untuk menjepit bagian bawah Leuit. Pintu terdapat di tengah-tengah dinding, terbuat dari papan kayu. Atap leuit yang berbentuk suhunan limasan, menggunakan atap asbes dengan wuwung dari genting.

\section{Gambar 16}

Leuit milik salah seorang warga.

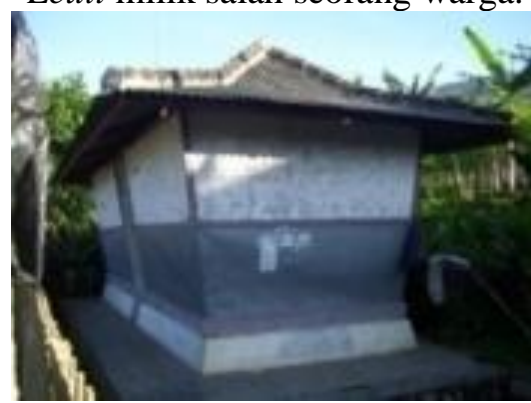

Sumber : Data Penelitian 2009

Bentuk bangunan Leuit lainnya, beberapa bagian berbeda dengan bentuk Leuit di atas. Bentuknya semakin ke atas tidak semakin besar; dindingnya terbuat dari gelondongan bambu, yang disusun rapat vertikal; bagian bawah dinding setinggi setengah badan kembali dilapisi lembaran seng; tiang yang berjumlah enam buah, masing-masing menggunakan siku-siku atau sisiku yang memperkokoh sambungan antara tiang dengan pangheret; pintu terbuat dari papan kayu, terletak di dinding sebelah sisi kiri.

\section{B. PENUTUP}

Bangunan peninggalan leluhur, yang tentunya telah berusia lama, yang keberadaannya baik bahan dan bentuk bangunannya sebagian besar tetap dipertahankan oleh keturunannya hingga kini, dapat dikatakan bangunan tersebut memiliki arsitektur tradisional. Imah kidul, Paseban, dan Leuit, demikian bangunan-bangunan peninggalan leluhur masyarakat Giri Jaya Padepokan, yang hingga kini masih digunakan oleh keturunannya. Imah Kidul sebagai bangunan tempat tinggal, dibangun oleh Eyang $\mathrm{Abu}$ sekitar tahun1831-an. Pada dasarnya bentuk bangunan berarsitektur tradisional Sunda, namun pada beberapa bagian ada pengaruh arsitektur Jawa dan Kolonial Belanda. Arsitektur Sunda terlihat dari bentuk rumahnya yang panggung dan memiliki kolong - walau hampir seluruh bagian kolong sudah ditutup dengan tembok (di depan, samping kiri, dan belakang), tetapi bentuk tatapakan masih terlihat jelas. Kemudian dinding menggunakan anyaman bambu dan papan kayu, lantai dari papan kayu, bentuk jendela menggunakan jendela jalosi, atap menggunakan suhunan panjang dengan memakai jure atau istilahnya bukaan pongpok, dan sebagainya. Arsitektur Jawa terlihat dari ornamen pada resplang berupa kembang karton. Ragam hiasnya berupa flora (bunga). Adapun arsitektur Kolonial Belanda terlihat pada bentuk jendela, selain tinggi dan daun jendelanya bukaan dua, juga kusen jendela bagian vertikalnya dipasang setinggi dinding rumah, mulai dari batas lalangit hingga lincar rumah. Adapun kusen bagian horizontalnya dipasang sesuai dengan tinggi jendela.Tinggi jendelanya sendiri mencapai hampir tiga per empat tinggi dinding. Daun jendelanya ada dua dengan masing-masing bukaan dua. Jendela pertama dari arah dalam berupa jendela kaca; yang kedua berupa jendela jalosi. Bentuk-bentuk jendela 
seperti ini dapat kita lihat pada rumahrumah peninggalan jaman Belanda dulu. Biasanya ada di mess-mess dan barak-barak tentara.

Adanya pengaruh arsitektur Jawa dan Kolonial Belanda pada bangunan Imah Kidul bukanlah hal yang mustahil. Hal itu mengingat didirikannya rumah tersebut sekitar tahun 1831an, manakala Eyang Kulon ada di sekitar daerah itu adalah untuk bertapa, memohon kepada sang Pencipta Bumi Alam, untuk keselamatan bangsa dan negara karena saat itu negeri sedang dijajah Belanda. Sehingga tidak menutup kemungkinan gaya arsitektur bangunan-bangunan Belanda mengilhami pembuatan Imah Kidul, khususnya pada bagian jendelanya.

Kemudian pengaruh arsitektur Jawa pun memungkinkan ada, hal itu mengingat saat itu Eyang Kulon bersahabat dengan Ama Santri yang mendapat sebutan Eyang Wetan dan bergelar Kyai Santri. Eyang Wetan ini berasal dari "Mangku Negara" Surakarta, yang bertemu dengan Eyang Kulon dan mengajak untuk pindah sekitar 1 kilometer ke bawah dari tempat bertapa di kaki Gunung Salak.

Mengenai keberadaan Imah Kidul di Giri Jaya Padepokan, leluhur mengamanahkan kepada keturunannya untuk memeliharanya dengan baik. Diibaratkan, seandainya rusak tiang satu, maka ganti yang satu itu dan tidak boleh dirubuhkan. Jadi, seharusnya bentuk asli harus tetap dijaga. Adapun kemudian pada beberapa bagian Imah Kidul mengalami perbaikan dan perubahan, contohnya pada Ruang Tamu di belakang, lantainya diubah menggunakan keramik. Hal itu adalah kewenangan sesepuh adat, tentunya dengan berbagai pertimbangan untuk kebaikan semuanya. Walaupun ada suara-suara yang menyayangkan perubahan tersebut terjadi. Demikian pula dengan adanya rencana pemugaran, yang bertanggung jawab melakukan perbaikan tersebut adalah sesepuh adat.

Paseban, yang dibangun pada saat kepemimpinan RD. Dadang (1964) merupakan upaya beliau dalam memfasilitasi peserta Upacara Seren Taun dan Mauludan yang banyak berdatangan dari berbagai daerah, seperti dari Kabupaten Sukabumi, Bogor, Bekasi, dan Tangerang. Sama halnya seperti pada bangunan Imah Kidul yang terdapat unsur-unsur pengaruh arsitektur Jawa, demikian pula dengan bangunan Paseban. Atap Paseban yang berbentuk limasan joglo ; empat tiang utama sebagai saka guru, kostruksi inti salah satu pendopo di Jawa; ornamen di lalangit Paseban. Semua itu adalah unsur-unsur dalam arsitektur Jawa.

Bentuk bangunan Leuit warga yang beratap limasan, joglo, tentunya telah mendapat pengaruh dari arsitektur Jawa. Kemudian telah terjadi beberapa perubahan dalam bentuk dan bahan bangunan leuit. Dadampar yang terbuat dari tembok, hampir memenuhi sekeliling dasar bangunan. Dinding yang terbuat dari gelondongan bambu yang disusun vertikal dan rapat. Pintu Leuit berukuran besar, sebesar pintu rumah. Umumnya Leuit memiliki pintu yang berukuran kecil, dan letaknya pun di atas sehingga jika akan masuk ke dalam harus menggunakan tangga. 


\section{DAFTAR PUSTAKA}

Budihardjo, Eko, Prof. Ir., M.Sc. (Ed). 1991.

Jatidiri Arsitektur Indonesia. Bandung : Alumni.

Budisantoso, S., Prof. DR. 1996.

Identitas Budaya dalam Arsitektur Tradisional dalam Menuju Arsitektur Indonesia Prof. Ir. Eko Budihardjo, M.Sc. (Ed.). Bandung : Alumni.

Frick, Heinz. 2001.

Pola Struktural dan Teknik Bangunan Indonesia - suatu Pendekatan Arsitektur Indonesia Melalui Pattern Language Secara Konstruktif dengan Contoh Arsitektur Jawa Tengah. Yogyakarta : Kanisius.

Kunto, Haryoto, Ir, dkk. 1996. Study Sejarah sosial dan Budaya Kawasan Saguling (Padalarang dan Sekitarnya). Bandung : Group Kota Kembang.

Imran, Ahda.

Menyoal Estetika Sunda dalam Pikiran Rakyat, 5 april 2008.
Muanas, Dasun, dkk. 1998.

Arsitektur Tradisional Daerah Jawa Barat. Jakarta : Depdikbud RI.

Sastrowardojo, Robi Sularto, Ir. 1996. Peranan Arsitektur Tradisional dalam Menuju Arsitektur Indonesia - Prof. Ir. Eko Budihardjo, M.Sc. (Ed.). Bandung : Alumni.

Syafwandi, Drs. 1985.

Menara Mesjid Kudus - dalam Tinjauan Sejarah dan Arsitektur. Jakarta : Bulan Bintang.

Wiartakusumah, Jamaludin. Seni Rupa - Mencari Estetika dalam Budaya Rupa Sunda dalam Pikiran Rakyat, 5 April 2008.

Wiryomartono, A. Bagoes P. 1995.

Seni Bangunan dan Seni Binakota di Indonesia : Kajian mengenai Konsep, Struktur, dan Elemen Fisik Kota Sejak Peradaban Hindu-Budha, Islam Hingga Sekarang. Jakarta : Gramedia Pustaka Utama.

Surat Kabar Buser Metropolitan. Edisi Maret 2009/Tahun IV/260. 